\title{
ANALYSIS OF MARKETING STRATEGY TO ACCELERATE BUSINESS GROWTH OF PAINTED VEIL DR.KERUDUNG LUKIS
}

\author{
${ }^{1}$ Mega Nuriza Firstiani Putri and ${ }^{2}$ Didip Diandra \\ ${ }^{1,2}$ Universitas Tanri Abeng \\ 1,2J1. Swadharma Raya No.58 Pesanggrahan Jakarta Selatan 12250 \\ 1mega.nuriza@student.tau.ac.id \\ 2didip.diandra@tau.ac.id
}

\begin{abstract}
This research analyzes the marketing strategy which is implemented by DR. Kerudung Lukis. This research used case study methods to gather the data and observe the natural phenomenon which exists in a set of data. The objective of this final project is to assign the right marketing strategy for $D R$. Kerudung Lukis to accelerate their business growth. The result of analysis shows that DR. Kerudung Lukis need to improve their 7Ps marketing mix strategy in several aspects such as; First, DR. Kerudung Lukis should optimize it current products. Second, DR. Kerudung Lukis should optimize its current promotions strategies. Third, DR. Kerudung Lukis should hire more employees, and the last DR. Kerudung Lukis should add some physical evidences to increase their brand awareness.
\end{abstract}

Keywords: Dr. Kerudung Lukis, 7Ps Marketing Mix, Brand Awareness

\section{INTRODUCTION}

"There are 20 million people in Indonesia who wearthe hijab. This is consistent with the development of Muslim fashion industry which is 7\% every year. Additionally, from 750,000 Small and Medium Industries (SMEs) in Indonesia, Muslim fashion industry control 30 percent of it. Of the total search "Muslim fashion" in Google, $77 \%$ is apparently derived from Indonesia. Then, $16 \%$ of which is from Malaysia and $2 \%$ from the UK as well as India. Currently, fashion still become mainstay to increase the image of Indonesian archipelago in international include muslim fashion industry" state General Director of small-medium industries, Euis Saedah (2016).

The large number of Indonesian people also can be opportunities for local industry. Because of that, cooperation among all parties is needed to motivate local product going to internasional market. Association of Indonesian Fashion Designers Entrepreneurs (APPMI) has the ideals to develop Indonesian Muslim fashion not only in the country, but also to the level of world. APPMI started the campaign of Muslim fashion industry with a route map Indonesian Fashion Muslim in 2015 can penetrate the ASEAN market, 2020 will be able to penetrate the Asian market, and in 2025 will be already taking the world market and targeting 7\% exports of Indonesian Muslim fashion (Islamiceconomic.org, 2016). To achieve these plans, all parties should cooperate well and encourage each other.

Creative industries especially Muslim fashion is quite resilient and continues to grow rapidly despite the current challenging conditions and the persistence of global economic uncertainty. The growth of the fashion industry in 2016 is expected to reach $8 \%$. Even the fashion industry was ranked the second after the culinary industry in Indonesia. It shows that there is big 
opportunities for Muslim fashion industry to develop. One of Muslim Fashion Company is DR.Kerudung Lukis, a local veil painting business of a Muslim fashion industry.

Based on the data given in the background, it shows that fashion industry especially for Muslim fashion industry has large opportunity. Because of that, Dr. Kerudung Lukis has huge

opportunities to develop their business. DR. Kerudung Lukis was established since 2014. Altough this business was in field for 2 years but the growth of Dr. Kerudung Lukis was very slow. It showed from maximum total order monthly around ten products. Therefore, the reseacher interested to observe the situation of Dr. Kerudung Lukis, and recommend the marketing strategies to increase their business performance as below:

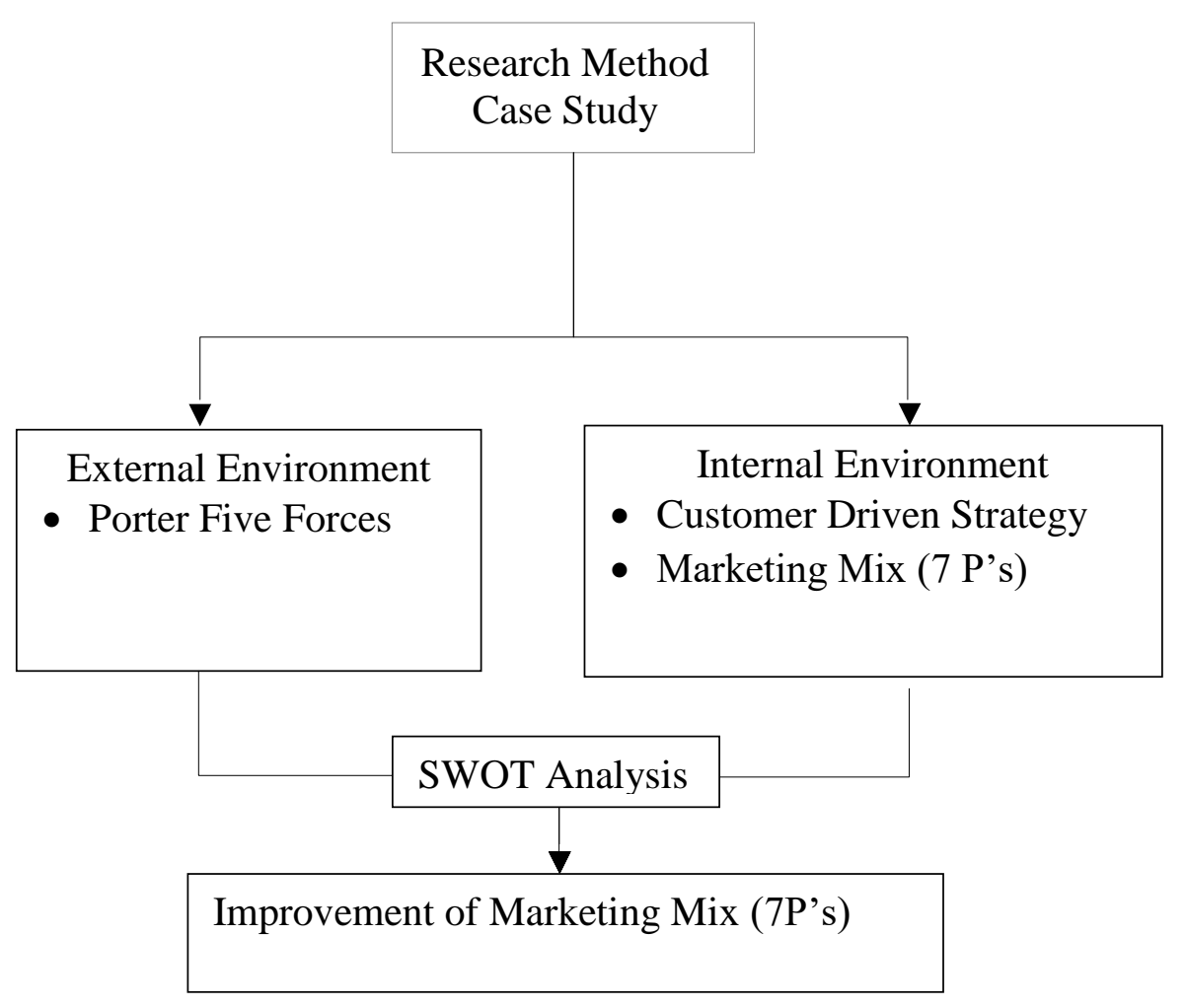

Figure 1. Research Methodology

\section{RESEARCH METHODOLOGY}

This research used case study methods to gathered data to find the suitable answer for research question. Case study is a unique way of observing any natural phenomenon which exists in a set of data, Yin (2009). Leedy \& Ormrod (2001) defined research methodology as the general approach the researcher takes in carrying out the research project by Williams (2007). Generally there are two methods to do data collection methods for this research, which are primary and secondary data.

Primary data is information that the researcher gather first hand through instruments such as interviews, surveys, focus groups, or observation such as: interview and observation. And 
secondary data are data that already exist by Uma \& Roger (2013) and collected from different resources such as textbooks, journal, and internet data collection.

\section{RESULTS AND DISCUSSIONS}

Based on the research performed in the above methodology, this paper aimed at exploring the marketing strategy recommendation to accelerate the business growth of painted veil DR.Kerudung Lukis through the analysis of external and internal environment as follows.

\section{External Environment]}

$>$ Porter Five Forces Analysis

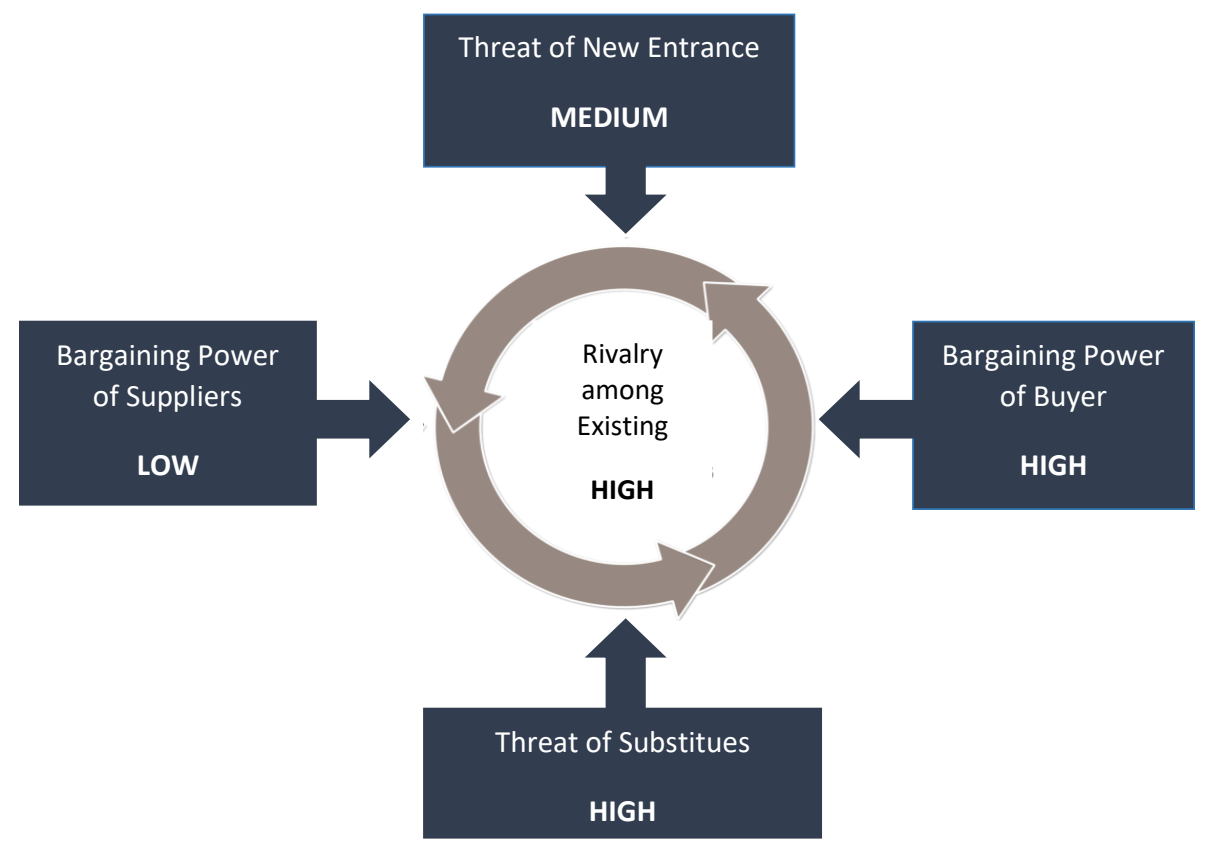

Figure 2. Porter's five forces analysis

Porter (1980) identified the five competitive forces - entry, threat of substitution, bargaining power of buyer, bargaining power of suppliers, and rivalry among competitors - reflect the fact that competition in an industry goes well beyond the established players. On Dr. Kerudung Lukis case, the porter's five forces model could be described as below:

a. Threat of New Entrance

The threat of entry into an industry depends on the barriers to entry that are present, by Porter (1980). In the case of Dr. Kerudung Lukis, the competition is very tight. The new competitor can easily to enter the market because only require low initial capital investment and does not have significant. Nevertheless, Dr. Kerudung Lukis offer differentiation to their product. They offer handmade painted veil which will be the threat to entry for new competitors because they should have special skill in the field of painting. So, the reseacher conclude that the threat of new entrant is relatively medium. 
b. Threat of Substitutes

A substitute product is a product from another industry that offers similar benefits to the consumer as the product produced by the firms within the industry by Wilkinson (2013). In the case of Dr. Kerudung Lukis there are numerous products which could be alternative for the customer such as painted shirt, intant veil, bergo, simple veil, and painted mukena. The customer could choose another substitute product instead of Dr. Kerudung Lukis product when their prices and quality are better. Since numerous of substituted product available, the reseacher conclude that the threat of substitutes Dr. Kerudung Lukis product is relatively high.

c. Bargaining Power of Buyer

The power of each of the industry's important buyer groups depends on a number of characteristics of its market situation compared with its overall business by Porter (1980). In the case of Dr. Kerudung Lukis, there are numerous main competitors of Dr. Kerudung Lukis which offer painted veil with another pattern. The more competitor and subtitues product, then bargaining power of buyer is stronger. So, the reseacher conclude that the bargaining power of buyer is relatively high.

d. Bargaining Power of Supplier

A strong supplier can make an industry more competitive and decrease profit potential for the buyer. On the other hand, a weak supplier can makes an industry less competitive and increases profit potential for the buyer by Wilkinson (2013). In this case, Dr. Kerudung Lukis choose supplier of textile from Pasar Tanah Abang for their supplier veil material. The more supplier whose sell the veil material of Dr. Kerudung Lukis product, then bargaining power of supplier is lower. So, the researcher conclude that the bargaining power of supplier is relatively low.

e. Rivalry among Existing Product

In the case of Dr. Kerudung Lukis, there are numerous competitor selling the same product, eventough they are using different pattern such as Salsiyah, Elfira and Quanesha painted veil. They promote their product through social media such as facebook and several trading online website. So, the reseacher conclude that the rivalry among existing product is relatively high.

\section{Internal Environment}

In this part, the researchers will identify several theories of marketing strategy using internal environment analysis as follows:

\section{$>$ Customer Driven Strategy}

There are four major steps in designing a customer-driven marketing strategy. The first step is for the company to decide what customer they will serve, and also the marketing segmentation and targeting. The final step is that the company has to select its value proposition and how it creates value for the customers, which is the differentiation and positioning by Kotler and Amstrong (2012).

a. Market Segmentation

Market segmentation is the process of dividing a market into distinct groups of buyers who have different needs, characteristics, or behaviors, and who might require separate products or marketing programs by Kotler\& Armstrong (2012). For consumers' market, marketing segmentation usually divided based on four factors, which are: 
i. Geographical Factor: Indonesia (Jakarta, Bogor, Depok, Tangerang, Bekasi, Medan, Solo,etc)

ii. Demographical Factor: Muslimah around 17 - 35 years old with the middle income.

iii. Psychological Factor: Muslimah who active, energic, and cheerful which suitable with the pattern of their product.

iv. Behavioral Factor: Muslimah who always follow the fashion trend.

b. $\quad$ Market Targeting

Dr. Kerudung Lukis has 2 types of product such as pashmina and square hijab. The fashionable customer tend to choose pashmina because they can make several style from one pashmina, in the other hand the square hijab is more preferred by muslimah who wear khimar because it is bigger in size and covered bigger area. Because of that, the researcher conclude that target market of Dr. Kerudung Lukis are women that using veil whether it is the khimar one or the hijab type which is interested into the uniqueness of doodle art. The researcher discovered that concentrated marketing is the best choice for the marketing target of Dr. Kerudung Lukis because their market segment only focuses to Muslim women that using veil and interested into doodle art.

c. Differentiation and Positioning

Porter's generic strategies (1980) describe three/four generic strategies, either lower cost, differentiated, or focus.Dr. Kerudung Lukis preferred focus differentiation as their competitive advantage strategies to develop the product that offers unique design of painted veil which produce by handmade for muslimah who wear khimar or hijab as their narrow target market.

There are five cells represent winning value propositions - differentiation and positioning: more for more, more for the same, more for less, the same for less, and less for much less by Kotler and Amstrong (2012). Dr. Kerudung Lukis use more for same as their value proposition because the price that they offer is almost the same with competitor, But Dr. Kerudung Lukis gives customer more advantage which is more modern pattern and better design. However, Dr. Kerudung Lukis try to set the price of their product very competitive with their competitor.

$>$ Marketing Mix (7P's)

The marketing mix is the set of tactical marketing tools that the firm blends to produce the response it wants in the target market by Kotler\& Armstrong (2012). The marketing mix can be collected into seven groups of variables, the 7P's.

a. Product

The product of Dr. Kerudung Lukisis painted veil. They have 2 types of products, square hijab and pashmina. The size of square hijab is $1.5 \mathrm{~m} \times 1.5 \mathrm{~m}$ and the size of pashmina is $2 \mathrm{~m} \times 0.6 \mathrm{~m}$. Dr. Kerudung Lukis offers more than 8 patterns that can be chosen by customer. However, the customer also can request their own design based on requirment. Dr. Kerudung Lukis will accept request design if the design is not living things such as human and animal pattern. After the customer get their product, DR.KerudungLukis will ask their testimony to maintain customer satisfaction.

b. Price

According to Zeithmal, Bitner, and Gremler (2006), there are fourapproaches to price structure: Cost-based pricing, Competition-based pricing, Demand-based pricing and Differential pricing.The price of DR.KerudungLukis product around Rp. $90.000-\mathrm{Rp} .150 .000$ based on difficulties level of pattern and the size of pattern. More difficult pattern will take more time and effort so the price also will higher than the simple one. But, Sometimes 
DR.KerudungLukis will give special discount for a season. DR.KerudungLukis choose competition based pricing strategies to attract more customer and increase brand awareness in society.

c. Place

Place is the distribution of the product or service and the location (s) of that distribution by Mooradian(2012). In this case, the production activity is located in Babakan Raya Street, Rt. 01/02 No. 52,DesaBabakan, Kec. Dramaga, Bogor, Jawa Barat. But, Dr. Kerudung Lukis does not have offline store. The distribution channel of Dr. Kerudung Lukis is via online, either via social media such as Facebook and Instagram or some online shopping such as Tokopedia.

d. Promotion

Dr. Kerudung Lukis did several promotional mixes to promote their product such as personal selling by word of mouth, advertising in social media, and sales promotion (giving price promotion). Advertising effectively and efficiently reaches large numbers of consumers and it's particularly effective at creating awareness and reminding large audience about the product or brand by Mooradian (2012).

In first time, the owner only promote her product around Bogor Agriculture Institute Campus by direct selling and Word of Mouth. Thus, Dr. Kerudung Lukis advertise their product via social media such as Facebook, Instagram, Path and What's Apps or Line messanger in order to leverage their target customer and increase their brand awareness. In Facebook and Instagram, Dr. Kerudung Lukis posts similar content, such as information about the product, kind of material, and description about the pattern. Not only that, Dr. Kerudung Lukis often giving special discount for a season to attract more customers.

e. People

In Dr. Kerudung Lukis, production activity has important role. Dr. Kerudung Lukis require human resource which has skill and experience in the art of painting, especially in doodle. In this case, Dr. Kerudung Lukis has 2 skillful employees to produced the Dr. Kerudung Lukis product with its own competitive advantage, and ensured the quality is remain the same at all times. However, this does not mean painters will speed up the production process in order to increase their salary, because Dr. Kerudung Lukis are more concerned about quality over quantity. Until now, Dr. Kerudung Lukis had yet opened the recruitment for public.

f. Process

Dr. Kerudung Lukis takes 2-3 days for produce one product because it produces by handmade. While there is numerous orders, Dr. Kerudung Lukis will discuss with customer for the estimation duration of work. After the deal, the customer will pay and the order will be process.

g. Physical Evidence

Physical evidence is the evidence or physical elements that influence the customer to value the company by Kotler\& Keller (2009). Dr. Kerudung Lukis create their logo and put in every product that they produce. They also put their logo in the pattern that they upload in social media.Dr. Kerudung Lukis promote their product via facebook and Instagram. It can be as the online physical evidence of Dr. Kerudung Lukis. 


\section{SWOT Analysis}

SWOT analysis is an overall evaluation of the company's strengths (S), weaknesses (W), opportunities $(\mathrm{O})$, and threats $(\mathrm{T})$. "The company should analyze its marketing environment to find attractive opportunities and identify environmental threats by Kotler \& Armstrong (2012).

a. Strength

There are several strength points of DR.KerudungLukis:

i. DR.Kerudung Lukis use doodle art as their product pattern,which could be as the uniqueness of DR.kerudung Lukis products.

ii. DR.Kerudung Lukis produce its product by handmade

iii. Customer could request the pattern design if its pattern is not living things such as human and animal.

iv. Eventough their product is unique, DR.KerudungLukis set reachable price for their products.

b. Weakness

However, besides some strong points mention above, DR.KerudungLukis also has some weakness:

i. DR.KerudungLukis has limited human resource. Until now, DR.KerudungLukis only has 2 employees as the painters.

ii. Production activities is the longest activities. DR.KerudungLukis often face crowded order and affect too long waiting list.

iii. DR.KerudungLukis only has two type of product, pashmina and square hijab.

iv. To increase the business growth, DR.KerudungLukisshould increase their brand awareness by optimized its promotion strategy.

c. Opportunities

There are some opportunities that could be beneficial for DR.KerudungLukis:

i. DR.KerudungLukis can add variant of product which still related with muslimah needed. For example: bergo, instant veil, and skirt.

ii. As developing SME in muslimah fashion industry, DR.KerudungLukis has chances to expand in national and international market.

iii. DR.KerudungLukis could increase their brand awareness by participating in bazaar.

d. Threats

There are few threats that DR.KerudungLukis may face:

i. The competition in DR.KerudungLukis case is very tight. New competitor can easily enter this industry because require low ccapital investment. To win in this competition, DR.KerudungLukis should maintain the quality of its product and increase their brand awareness.

ii. Availability of subtitues product such as painted bag, painted shoes, and painted shirt can become a threat for DR.KerudungLukis.

\section{Improvement of Marketing Mix}

There are several suggestions of improvement for Dr. Kerudung Lukis in terms of new model of 7P's Marketing Strategy, which are product, promotion, people, process and physical 
evidence area with the aim of improve the performance of marketing and business activities as well as to solve the problems ofDr. Kerudung Lukis. Below are the strategies:

1) Product

Several suggestion to develop its current product below:

a. Add variant product

By adding the kind of veil, Dr. Kerudung Lukis could reach more customers. Dr. Kerudung Lukis also could add variant product which still related with muslimah needed such as skirts and muslimah shirts.

b. Give the name of pattern

Dr. Kerudung Lukis could give the name to each pattern that they has with unique theme which draw the big picture of Dr. Kerudung Lukis. Change the number with unique name will give pshycological effect for its pattern to be more interested.

2) Promotion

Below the promotion strategy that Dr. Kerudung Lukis should add:

a. Participated any exhibition

Currently, Dr. Kerudung Lukis never yet participated in any exhibition or bazaar. The exhibition or bazaar can become an effective promotion because it would be visited a lot of people as the new potensial customer of DR. Kerudung

b. Create the website

There are numerous similar local competitors who already have websites. However, reseacher think that website can also be a promising platform. To optimize the benefit of using website, Dr. Kerudung Lukis also could use Search Engine Optimization (SEO) in order to reach high ranking in the page of search engine result.

c. Community Management

Community is a group of people who have similar interest. To optimize its knowledge about muslimah fashion business strategy, the reseacher recommend Dr. Kerudung Lukis to join fashion muslimah business community. Dr. Kerudung Lukis also could leverage their connection and benchmarking about the business strategy by joining community.

3) People

To solve the lack of human resources in Dr. Kerudung Lukis, reseacher recommend the owner to open recruitment especially for painter.Effective recruitment process can support Dr. Kerudung Lukis to develop the business. In recruitment process, Dr. Kerudung Lukis should gives painted test according to what Dr. Kerudung Lukisstandard.

4) Process

Until now, Dr. Kerudung Lukis product only made by order. The reseacher think that it is very inhibit the business performance. To solve this problem, the reseacher recommend to Dr. Kerudung Lukis to produce the stocks of product. So, while the customer who wants it faster, Dr. Kerudung Lukis could recommend them to choose the available of stock.

5) Physical evidence

There are several physical evidence that Dr. Kerudung Lukis should add:

a. Offline stores

In this case, the production activity is located in Babakan Raya Street, Dramaga Bogor. But, Dr. Kerudung Lukis have not offline store. However, reseacher recommend to Dr. Kerudung Lukis to consider about offline store.

b. Business card

To support Dr. Kerudung Lukis promotion strategy, the reseacher recommend this business to make their own business card. It could help customer easier to remember with Dr. 
Kerudung Lukis after a first meet. Business card also could help Dr. Kerudung Lukis to add their link.

\section{CONCLUSION}

In this case study, reseachers identify the business activites and marketing strategies which implemented by Dr. Kerudung Lukis. However, the reseacher found several issues and solution which could be the opportunity to improve the marketing performance and business activites of Dr. Kerudung Lukis. First, Dr. Kerudung Lukis not yet optimized it current product. Thus, Dr. Kerudung Lukis also has not yet optimized its current promotions strategies. Next, Dr. Kerudung Lukis is still lack of human resource as the painter, and the last Dr. Kerudung Lukis is still lack of physical evidence.

Discussion about generic strategy, Dr. Kerudung Lukis preferred focus differentiation as their competitive advantage. The reseacher also found several issues in 7Ps marketing mix that have to be solved, there are: on product, promotion, people, and physical evidence.

\section{REFERENCES}

Bamford, Charles \&Bruton, Garry. 2011. Entrepreneurship a Small Business Approach. New York: McGraw-Hill.

Islamic Economic Society. 2016. Islamic Fashion, viewed $20^{\text {th }}$ June 2016, $<<$ http://www.islamiceconomic.org/indonesian-islamic-fashion-industry $>>$

Kotler, Philip \& Armstrong, Gary. 2012. Principle of Marketing: 14 ${ }^{\text {th }}$ edn. London: Pearson Education.

Mooradian, T., Matzler, K., \& Ring, L. 2012. Strategic Marketing. London: Pearson Education.

Porter, Michael E. 1985. Competitive Advantage: Creating and Sustaining Superior Performance, New York: The Free Press.

1980. Competitive Strategy: Techniques for Analyzing Industries and Competitors, New York: The Free Press.

Saedah, Euis. 2016. Busana Muslim Berjaya, KementrianPerindustrian, viewed $20^{\text {th }}$ June 2016,<<http://www.kemenperin.go.id/artikel/ 15563/Busana-Muslim-Berjaya 〉>

Silverman, David. 2000. Doing qualitative research: a practical handbook, Sage Publication: London.

Uma, S. \& Roger, B. 2013. Research Methods for Business, $6^{\text {th }}$ edn. Wiley: U.K.

Wilkinson, Jamie. 2013. Threat of New Entrants (one of Porter's Five Forces), viewed $28^{\text {th }}$ August 2016, <<http://strategiccfo.com/one-of-porters-five-forces/>> 